The Geneva Papers on Risk and Insurance, 20 (No. 75, April 1995), 166-179

\title{
Understanding the Korean Insurance Market and Its Future Outlook
}

\author{
by Hyung-Sup Shim*
}

\section{Brief history of the Korean insurance industry}

Insurance was first introduced in Korea in 1883 when Hong Kong Fire Insurance Company opened its agency office in Korea. The domestic insurance industry launched into business when Chosun Life Insurance Company was established in 1921 and Chosun Fire \& Marine Insurance Company in 1922.

Until the 1950s, the insurance industry could not perform its function worthily since its foundation for growth was still fragile and potential consumers had little understanding of insurance. Political, economic and social unstability, and ongoing inflation in the country were also negative factors. In the 1960 s, a breakthrough for the insurance industry came as the first five-year economic development plan was forwarded by the Government, aiming at industrialization and establishment of a self-supporting economic structure.

In the early 1960s, the insurance industry formed its basis of growth through the Government's implementation of promotion policies in respect of insurance business, capital expansion and consolidation of insurance companies. In January 1962, the constitutional foundation was arranged by enacting relevant laws such as the Commercial Law, Insurance Business Law, Law on Regulating Insurance Solicitation, and Law on Foreign Insurers.

The Korean economy made rapid growth and national income showed a sharp increase in the 1960s, thanks to successful accomplishment of two consecutive five-year economic development plans, which provided the insurance industry with a period of development. However, the weakness in soliciting personal and household lines set limits to genuine market expansion.

In the meanwhile, the Korean Reinsurance Corporation was established in 1963 as a government-run company, under the Laws on the Korean Reinsurance Corporation, to

Chairman \& President Korean Reinsurance Company. 
provide reinsurance facilities and to contribute to the sound development of the insurance industry. It was also designed to maximize utilization of the domestic insurance industry's underwriting capacity.

In the 1970 s, remarkable growth was recorded in the national economy and in the insurance industry as well, as the economic development plans were successfully carried out. In 1977, the Government enforced modernization of the insurance industry, with the twin aims of enhancing public confidence in the industry and reinforcing its international competitiveness, by upgrading underwriting techniques and improving the constitutions of insurance companies.

The Insurance Business Law was revised accordingly at the end of 1977, in line with the basic principles of (a) amplifying the function of the insurance industry for social security and mobilization of domestic capital, (b) modifying various systems to protect policyholders, (c) reinforcing the international competitiveness of the insurance industry, and (d) restructuring the Korean Reinsurance Corporation into a public company, that is, the Korean Reinsurance Company.

The Korean economy continued to develop favorably in the 1980 s, backed up by improved export growth in close connection with the devaluation of the domestic currency against the U.S. dollar, lower oil prices, and the fall of international interest rates. In this changed economic environment, the insurance industry also achieved continuous and rapid progress - in quantity as well as in quality - to take up an important position in the Korean financial industry.

However, the high growth of the insurance industry, especially that of the life insurance industry, brought about the necessity of market opening, and caused a rush to establish new life insurance companies. In the early 1980s, opening the life insurance market to foreign insurers became the focus. In 1987, as a result, LINA and ALICO, member companies of CIGNA Group and AIG Group, respectively, started business operations after being licensed to establish life insurance companies.

Afterwards, the Government received a flood of applications for establishment both of joint-ventures with foreign companies, and new domestic life insurance companies. At present in Korea, life insurance companies number 33, including three foreign companies and seven joint-ventures.

On the other hand, two foreign non-life insurance companies have been operating in Korea since 1968, that is, AHA and Hartford (CIGNA, at present), and since 1987, a number of foreign reinsurance companies and brokers have been allowed to advance into the Korean market by establishing liaison offices. Now, 17 non-life insurance companies are conducting business, including three foreign companies, two fidelity and surety companies, and one reinsurance company.

As detailed above, the development process of the Korean insurance industry can be classified as having followed four stages:

(1) Infancy stage before 1960s

(2) Childhood stage in $1960 \mathrm{~s}$

(3) Adolescence stage in $1970 \mathrm{~s}$

: Birth of insurance industry

(4) Market opening stage since 1980s

: Formation of growth foundation

: Modernization of the industry

: Internationalization of the industry 


\section{Overview of the Korean insurance industry}

Growth trend and operating results of the insurance market

The Korean insurance industry underwent a big change in the early 1960s toward epoch-making development. There was a substantial increase of life insurance premium centering around group insurance contracts, along with a new governmental policy appointing insurance companies as saving institutions, to help mobilize domestic capital in support of the economic development plans.

The growth of insurance premiums during the period from 1965 to 1993 was remarkable. The total premium of five billion Won (US\$ 19 million) for both life and non-life insurance, written in 1965, increased to 30,833 billion Won (US\$38,209 million) in 1993.

During this timespan the life premium increased 8,018 times $(2,615$ times in US $\$$ ) and the non-life premium 3,390 times (1,105 times in US $\$$ ), which made the overall insurance premium in 1993 6,167 times (2,011 times in US\$) greater than that in 1965.

Graph 1 Growth trend of written premium

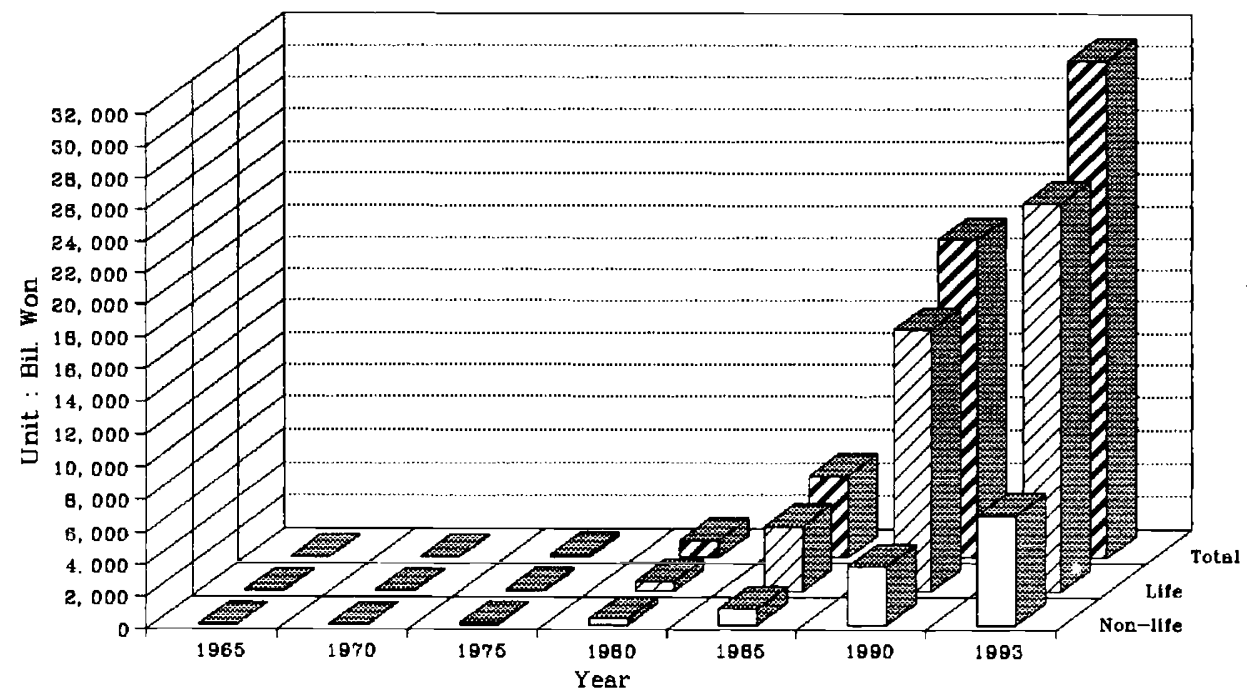

\section{Source: Insurance Supervisory Board of Korea}

Total assets of the insurance industry in 1965 were nine billion Won (US $\$ 34$ million), a figure which increased to 58,173 billion Won (US $\$ 72,089$ million) by 1993 . The life insurance market increased 10,040 times (3,293 times in US\$), and the non-life market 1,993 times (654 times in US\$), which equates to a 6,464 times' (2,120 times' in US\$) increase in total market assets. 
Graph 2 Growth trend of total assets

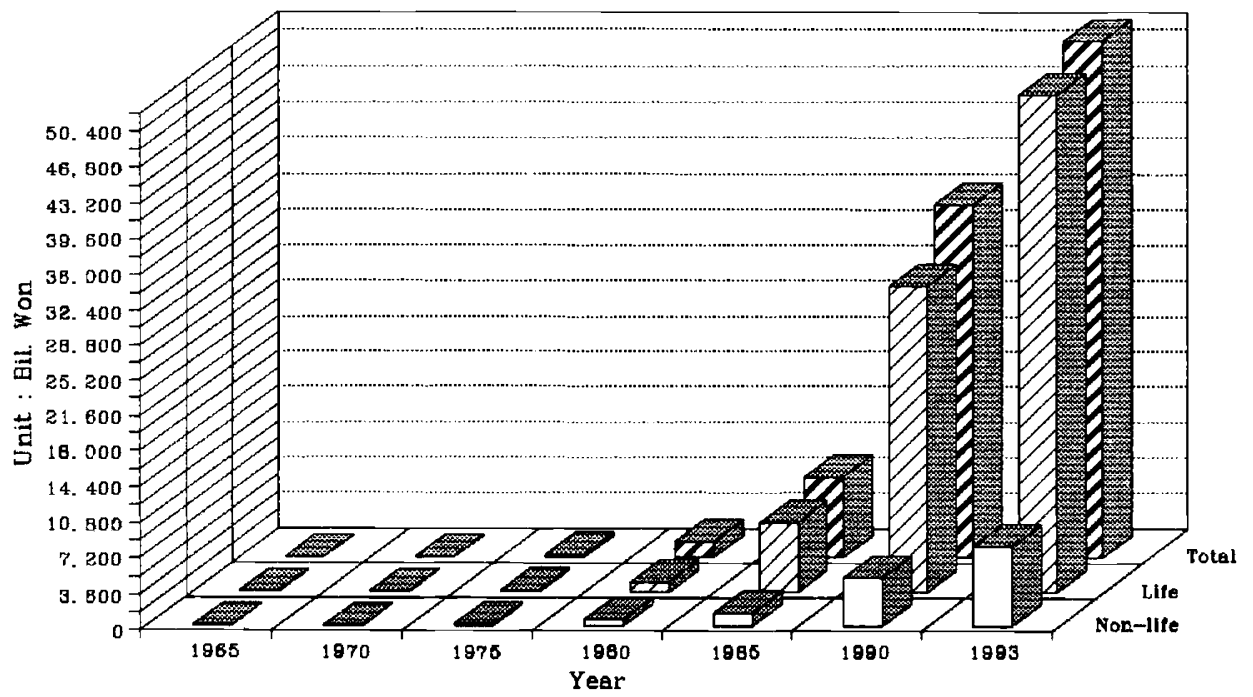

Source: Insurance Supervisory Board of Korea

The continuous and rapid progress of the Korean insurance industry for the last three decades allowed it, as of 1992, to take a position as the sixth largest member of the world insurance market on a written premium basis: more specifically, life insurance ranked sixth, and non-life twelfth. Also, its premium as a percentage of gross domestic product ranked second in the world.

\section{Latest operating result of life insurance}

Financial reform measures such as the real-name financial transaction system and the interest liberalization plan pursued by the Government in 1993 contributed greatly to the sound development of the national economy. To parallel reform efforts sought by the Government, Korean life insurance companies also strived to exercise effective management strategies and develop diversified products to meet varying consumer needs.

Life insurance contracts are divided into individual policies and group policies. Individual policies are subdivided into pure endowment including educational insurance and annuities, term insurance (insurance against death), and endowment including short term savings insurance.

In 1993 the life insurance premium income reached 24,053 billion Won (US $\$ 29,807$ million), an increase of $6.2 \%$ over 22,641 billion Won (US\$28,765 million) the year before. The premium income for pure endowment amounted to 15,051 billion Won (US\$18,651 million) - a $24.3 \%$ increase over 1992 , and $62.6 \%$ of the total life insurance premium. 
Term insurance recorded 1,451 billion Won (US\$ 1,798 million), a $76.7 \%$ increase and $6.0 \%$ share. The above figures demonstrate that insureds are still attaching greater importance to the saving function of life insurance than to its security function. Meanwhile, the premium of endowment insurance decreased by $38.3 \%$ to 3,385 billion Won (US $\$ 4,195$ million), accounting for $14.1 \%$ of all life insurance.

Individual insurance marked an $8.0 \%$ increase compared with the year before, and group insurance a $1.3 \%$ decrease. The composition share of the former reached $82.7 \%$, and that of the latter $17.3 \%$.

Graph 3 Written premiums of life insurance
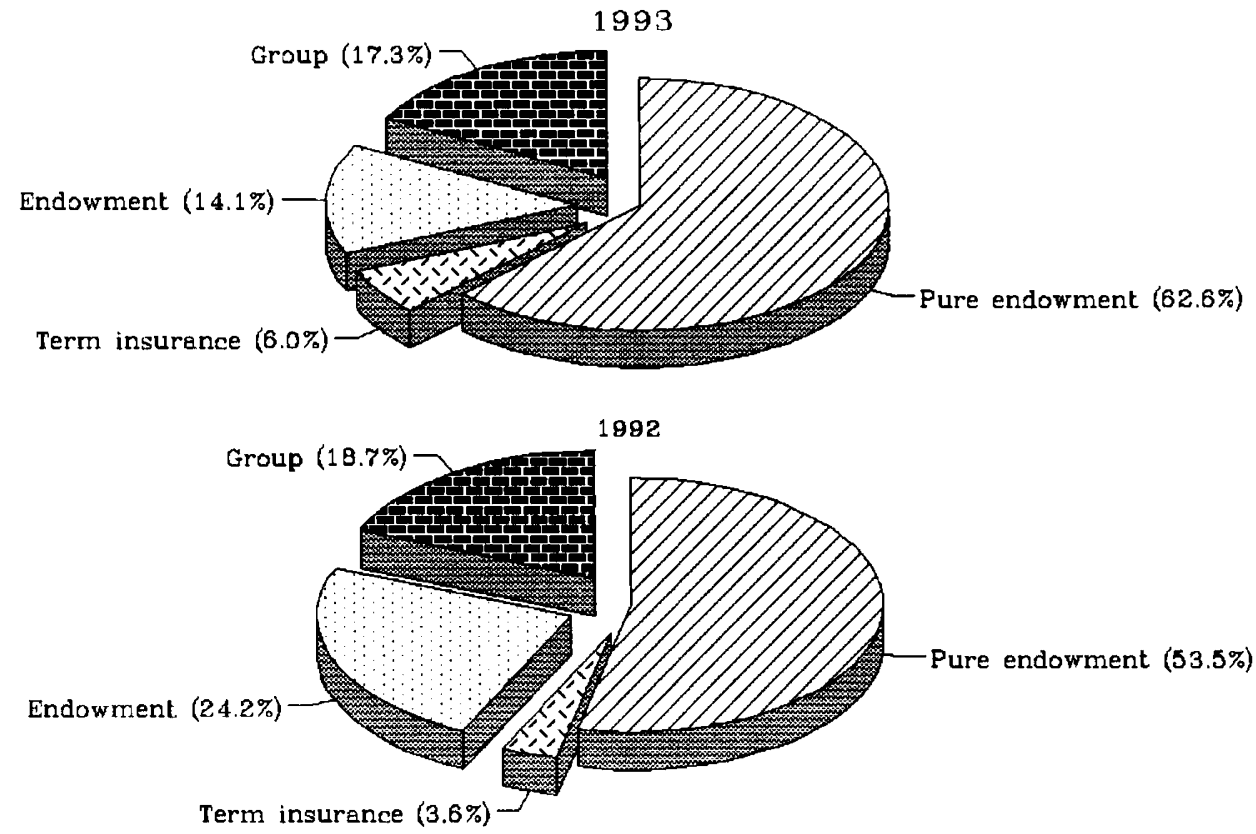

Source: Insurance Supervisory Board of Korea

Insurance benefits paid to policyholders and beneficiaries amounted to 19,783 billion Won (US\$ 24,515 million) in 1993, which included claims paid, refunds on lapses and surrender, other refunds, and policyholders' dividends, and represented a $12.5 \%$ increase over the previous year. The ratio of insurance benefits to premiums was $82.2 \%$, a 4.5 percentage points' increase over 1992 . Operating expenses increased by $17.6 \%$ to 3,611 billion Won (US\$ 4,475 million), and the expense ratio was thus $15.0 \%$, an increase of 1.4 percentage points over the year before. 
To ensure efficiency and financial soundness, domestic insurance companies' management of their assets is strictly controlled by the Assets Management Guideline set forth by the Ministry of Finance, and by the Insurance Business Law and its enforcement decrees.

As of the end of 1993, total assets amounted to 50,200 billion Won (US\$62,209 million), an $11.2 \%$ increase compared to a year before, and operating assets had reached 46,762 billion Won (US\$ 57,948 million), an increase of $10.5 \%$. However, the asset operating ratio was $93.2 \%$, reflecting a decrease of 0.5 of a percentage point from the preceding year, mainly due to the increase of newly-established companies' deferred assets. The assets yield ratio for 1993 was $10.8 \%$, a decrease of 1.1 percentage points over the preceding year. This reflects a steadfast downward trend, which could be attributed to the decrease in investment income, brought about in turn by a combination of falling corporate loan demand and lowered interest rates since interest rate liberalization measures were initiated.

Graph 4 Written premiums of non-life insurance

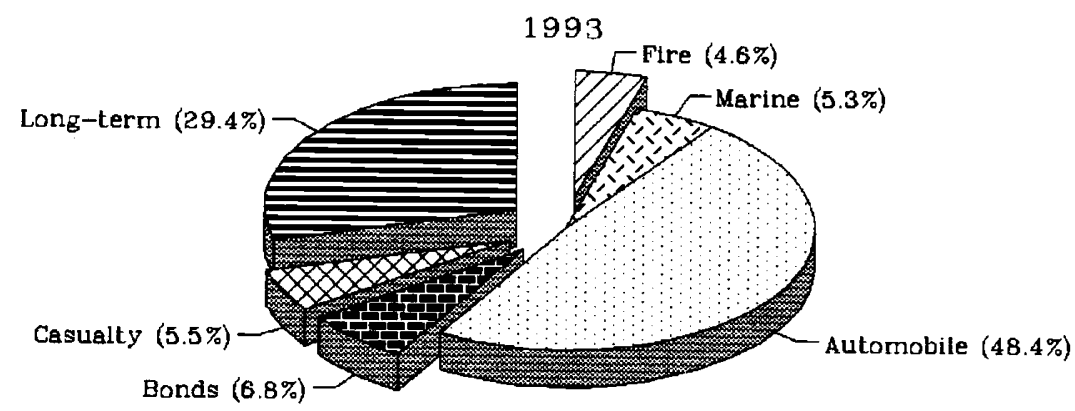

1992

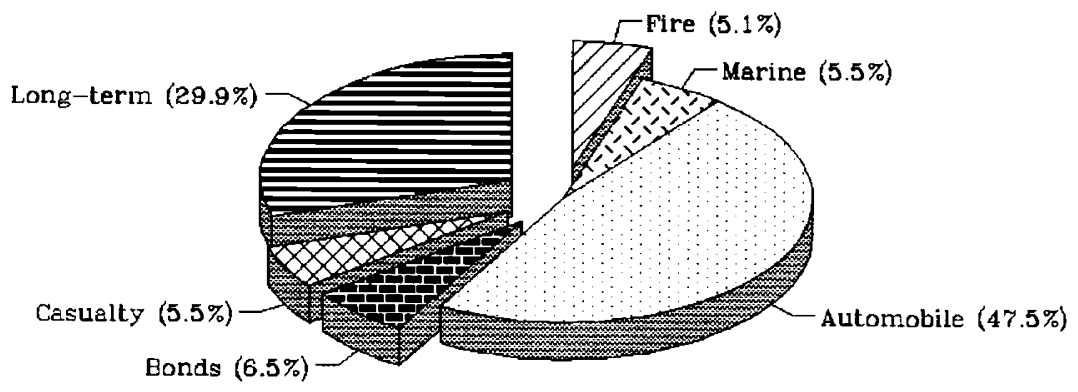

Source: Korea Non-Life Insurance Association

At the end of 1993, the total amount in policy reserves was 48,151 billion Won (US\$ 59,670 million), an increase of $10.8 \%$ over the year before, out of which dividend reserves 
were 1,339 billion Won (US\$ 1,659 million) - up $15.3 \%$ over 1992 . Policy reserves also included 45,980 billion Won (US\$ 56,979 million) as premium reserves, 33 billion Won (US\$ 41 million) as unearned premium, and 799 billion Won (US\$ 990 million) as outstanding loss amount.

\section{Latest operating results of non-life insurance and reinsurance}

The domestic non-life insurance industry is facing a new era of unbounded competition, triggered by the recent worldwide trend toward internationalization, market opening, and liberalization, as well as by changes in the national economic system such as the introduction of the real-name financial transaction system, interest rate liberalization, and deregulation in the governmental administration sector.

Gross premiums of non-life insurance companies written in 1993 stood at 6,780 billion Won (US\$ 8,402 million), up $17.3 \%$ over the preceding year but 4.9 percentage points lower than the increase rate of $22.2 \%$ in 1992 . In respect of market share, automobile insurance, the largest line in terms of premium income, increased to $48.4 \%$ from $47.5 \%$ the previous year, and bonds expanded to $6.8 \%$. The casualty line maintained its share of $5.5 \%$ while other branches fell slightly: fire insurance to $4.6 \%$, marine insurance to $5.3 \%$, and long-term insurance to $29.4 \%$.

The incurred loss in 1993 amounted to 5,843 billion Won (US\$ 7,241 million), including paid claims of 4,289 billion Won (US\$ 5,315 million). The incurred loss ratio worsened by 2.6 percentage points to $92.9 \%$, compared with $90.3 \%$ in 1992 , a deterioration attributable mainly to the poor results of automobile insurance.

Table 1 Incurred loss of non-life insurance by class

Units : Billion Won, \%

\begin{tabular}{|l|r|r|r|r|}
\hline \multirow{2}{*}{ Class } & \multicolumn{2}{|c|}{1993} & \multicolumn{2}{c|}{1992} \\
\cline { 2 - 5 } & Amount & Loss Ratio & Amount & Loss Ratio \\
\hline Fire & 101 & 47.9 & 87 & 45.4 \\
Marine & 72 & 33.6 & 68 & 38.1 \\
Automobile & 3,155 & 103.8 & 2,314 & 89.3 \\
Bonds & 372 & 101.1 & 572 & 172.1 \\
Casualty & 204 & 62.1 & 181 & 62.9 \\
Long-Term & 1,939 & 91.2 & 1,468 & 92.5 \\
\hline Total & 5,843 & 92.9 & 4,690 & 90.3 \\
\hline
\end{tabular}

Source: Korea Non-Life Insurance Association 
The underwriting result, comprising earned premium less incurred loss, increase of catastrophe reserve and net management expenses, deteriorated by 201 biliion Won (US $\$$ 249 million) to a 931-billion-Won (US\$1,154 million) deficit in fiscal year 1993. The ratio of profit over earned premium also deteriorated by 0.7 of a percentage point to a negative $14.8 \%$. Consequently, net income worsened by 31 billion Won (US\$ 38 million) to a 181 billion-Won (US\$224 million) deficit.

Total assets had reached 7,973 billion Won (US\$ 9,880 million) as of the end of fiscal year 1993 , up $17.4 \%$ from the previous year. The asset operating ratio had increased by 0.9 of a percentage point to $81.9 \%$. Investment income was 704 billion Won (US\$ 872 million), an increase of $23.7 \%$ compared with the year before, and the ratio of investment income over working assets had also increased, by 0.6 of a percentage point to $12.4 \%$.

As for overseas reinsurance, inward reinsurance premium income was US\$ 43 million, decreased by $0.2 \%$, but outward reinsurance premium was US\$ 401 million, up $11.6 \%$ from the previous year. The ratio of inward reinsurance premium over outward decreased by 1.3 percentage points to $10.7 \%$. The inward reinsurance commission ratio was $31.3 \%$, but the outward one was $15.7 \%$.

Reinsurance claims paid decreased by $6.1 \%$ to US $\$ 39$ million, and the loss ratio also decreased, by 5.7 percentage points to $91.4 \%$, while recovered claims increased by $39.8 \%$ to US\$278 million and the loss ratio deteriorated by 14.0 percentage points to $69.4 \%$.

Table 2 Overseas reinsurance result. Units: US\$ Million

\begin{tabular}{|l|r|r|r|r|}
\hline \multirow{2}{*}{ Item } & \multicolumn{2}{|c|}{ Inward } & \multicolumn{2}{c|}{ Outward } \\
\cline { 2 - 5 } & 1993 & 1992 & 1993 & 1992 \\
\hline R / I Premium & 43 & 43 & 401 & 359 \\
Commission & 13 & 14 & 63 & 69 \\
Claim & 39 & 42 & 278 & 199 \\
Balance & -9 & -13 & -60 & -91 \\
\hline
\end{tabular}

Source : Korea Non-Life Insurance Association

\section{Korean Re's roles and contributions}

Korean $\mathrm{Re}$, the only professional reinsurer in Korea, has played a leading role by acting as the window for overseas inward-and-outward reinsurance of domestic companies, and has strictly overseen premium and claim settlements among domestic companies, thus strengthening the financial position of Korea's direct insurance companies.

Korean $\mathrm{Re}$ has been providing the substantial reinsurance capacity required by local direct insurers, which use its retrocession capacity. It also sets the relevant rates, to prevent excessive competition on rate quotations, to alleviate reinsurers' security problems, and to avert rate conflicts. 
Its 32 years of experience have helped it develop extensive reinsurance techniques, knowledge, and expertise, so that the company is now able to provide a full range of underwriting services for both proportional and non- proportional business.

Financial highlights of Korean Re for the year ended March 31, 1994 are as follows :

Table 3 Financial Highlights of Korean Re

\begin{tabular}{|l|c|c|c|c|}
\hline \multirow{2}{*}{ Item } & \multicolumn{2}{|c|}{1993} & \multicolumn{2}{c|}{1992} \\
\cline { 2 - 5 } & Bio. Won & US\$ Mio. & Bio. Won & US\$ Mio. \\
\hline Gross Premiums Written & 660 & 818 & 590 & 750 \\
Net Retained Premiums & 351 & 434 & 306 & 388 \\
Technical Reserves & 313 & 388 & 297 & 377 \\
Total Assets & 716 & 888 & 661 & 840 \\
Policyholders' Surplus & 179 & 222 & 138 & 175 \\
\hline
\end{tabular}

Source : Korean Reinsurance Company

\section{Recent business environment}

\section{Market opening. Globalization}

Since the mid-eighties the global financial market environment has been changing more widely than ever before, in the midst of economic and political changes such as the opening of Eastern Europe, unification of the European Community, and the multilateral trade negotiations of the Uruguay Round.

The international dynamic structure is moving towards the point where it will give priority to economic considerations over political ideology. This trend of change is accelerating globalization of the financial market and universal banking, and every economic party is being forced to confront the era of market-opening and liberalization while yet unprepared. The Korean insurance industry also accepts this trend as an unavoidable reality.

To meet this change in the international financial environment, the government authority is promoting policies to enhance the efficiency of the insurance industry, through market-opening, self-regulation, and a market economy led by private enterprise instead of a governmental protective policy.

The opening of the life insurance market started in 1987 with the establishment of two foreign life insurance companies, and evolved considerably thereafter. Market entry of non-life insurance companies through establishment of branch offices was also allowed; liberalization in transacting reinsurance and cargo insurance was implemented by stages.

Market opening and internationalization might have an affirmative effect, from the standpoint of protecting consumers' rights, as it will enable consumers to have a wider 
choice of insurance policies and coverages, to their advantage. On the other hand, there will be several short-term negative effects, such as market disorder caused by fierce competition, management crises of some domestic companies, and outflow of domestic capital to overseas countries.

\section{Deregulation}

The present Korean government has been strongly implementing deregulation in its administration sector since it set sail in 1993. In applying this policy to the insurance industry, it bases its procedure on awareness that restrictions stem not only from legislation but also from market practices in domestic insurance circles.

To proceed with deregulation, the Government has been abolishing restrictions through substantial amendment of insurance-related laws and regulations. The insurance industry has also been lifting traditional bans included as part of its operative practice.

Deregulation in the insurance industry will, hopefully, lead to fair competition between companies, as they make the most of self-regulation and creativity, and should eventually enhance the public convenience. It is expected that domestic insurance companies will also benefit by gradual deregulation in the fields of product, price, solicitation, and assets management, which will mean an increase in their managerial effectiveness through competition.

Traditionally, insurance companies have been easily able to establish their future strategies based only on past experience, because the market environment had never changed greatly but remained simple and static due to strict regulations. Deregulation and liberalization mean that the market situation is becoming changeable and flexible, as well as that uncertainty is increasing. It is to be realized that increments in uncertainty not only jeopardize management but also promote new opportunities.

Korean insurance companies, therefore, are being requested to reorganize their management systems voluntarily, to make them more flexible in adapting to environmental changes, as their international competitiveness is more required now than ever.

\section{Price liberalization}

Premium decontrol was the first issue that was discussed with deep concern when deregulation and market opening of the insurance market were being planned.

The reason is that, when foreign insurance companies enter the domestic market, they are unable to compete effectively with local companies unless the current tariff and approved rate systems are modified.

Life insurance premium rating was less controversial because of its characteristics: simple coverage, its strong financing function, and its nature as insurance-cum-dividend. In non-life insurance, price liberalization became the highlighted issue because it was regarded as a major prerequisite condition of deregulation and market opening.

Premium rate liberalization in non-life insurance will be implemented according to a three stage time-table. At each stage, pricing of certain classes will become free within preset limits, and two years afterwards, the limits will be abolished. 
Table 4 Schedule of price liberalization by class

\begin{tabular}{|c|l|c|}
\hline Stage & \multicolumn{1}{c|}{ Class } & Schedule \\
\hline First & $\begin{array}{l}\text { - Hull insurance } \\
\text { - Corporate casualty insurance } \\
\text { - Transportation, Theft, Engineering, Liability, } \\
\text { Workmen's Compensation, Inland Floater, etc. }\end{array}$ & '94.4. \\
\hline Second & $\begin{array}{l}\text { - Cargo insurance } \\
\text { - Fire insurance } \\
\text { - Fidelity \& surety } \\
\text { Thdividual casualty insurance } \\
\text { - Accident, Comprehensive }\end{array}$ & '95.4. \\
\hline - Long-term insurance & $' 96.4$. \\
\hline
\end{tabular}

When the tariff rate system ceases to exist following the liberalization of the insurance price, the principle of commercial competition will be brought into the market. This principle will enable the consumer to purchase an insurance policy with more reasonable premiums, and the insurance company to employ a more flexible rate system, through rating based on underwriting results. While these are recognized as positive consequences, there are also worries in the local market of such negative consequences as the expanding influence of large insurance companies, and an ever-worsening cut-throat competition through excessively lowered insurance prices for market share pre-emption.

\section{Changes in the solicitation system}

The opening of the solicitation market means the replacement of the traditional exclusive agency system with an independent agency and broker system, under which sales agents are able to deal with products of various insurance companies. The sequence of its introduction will be led by the independent agency system rather than the broker system. This schedule has been adopted in line with the viewpoint that the broker system can work for its intended function only after there is differentiation of insurance products and pricing, and, furthermore, that the independent agency system will have a comparatively less severe impact on the market, as insurance companies will be able to have some control over the independent agencies which will sell the insurance products on their behalf.

The independent agency system is also scheduled to be introduced into the market in phases - in 1996 for non-life insurance and in 1997 for life insurance - until the market is considered mature enough to adapt itself to this changing situation. This maturity of the market will be achieved through the multiple agency system, under which agents will be able to sell the insurance products of two insurance companies.

In the meantime, the broker system will be introduced into the market after satisfying prior conditions such as the complete implementation of price liberalization and the full settling in of the independent agency system. 
As the local market is completely inexperienced in the operation of the independent agency system, the existence of large-size professional and experienced foreign agencies in the local market is expected to substantially impact on the existing local soliciting system.

\section{Diversification of insurance needs}

Recently both the way of life and the level of consciousness of the Korean people have greatly changed. Consequently, there is an increased multiformity of the consumers' purchasing patterns and the people's sense of value. The enhanced national income level and the expanded proportion of elderly people have rearranged the peoples' life cycle, and the sophistication of the industrial structure and the rapid growth of the information industry have made the needed coverage more complicated.

The increased demands for a cultural life, in the wake of the growth of the national income, have created considerable insurance needs relating to sports, leisure and activities of various interests. Brand-new and various risks are looming consequent upon the developments of science technology, and the sophistication and complexity of the society. The emergence of intangible property risk is one example.

These kinds of changes in a society inevitably bring about diversity of consumer needs. In the future, numerous new and varied risks will continue to appear, as the society keeps on growing and transition to the aging society accelerates. In this context, it will be required to develop insurance products providing comprehensive services in these sectors.

The competitive power of the insurance industry has to be cultivated and exerted in various areas such as products, price, marketing structure, and services; however, first of all, the emphasis should be on developing specialized insurance products which can be distinctly differentiated from those of the other financial industries. The conventional products - savings-oriented insurance, employee retirement insurance, pension insurance, and the general corporate insurance - will not satisfy the consumers' diversified needs anymore. The industry will gradually lose its competitive edge unless the limitations of those products are overcome.

\section{Strong consumerism}

As noted, the consumers' needs have lately become more diversified while their level of consciousness is getting higher. Under such market circumstances, with severe competition due to market opening and liberalization, the differentiated services in insurance lead directly to improved marketing outcomes. It should, therefore, be duly recognized that the enhanced satisfaction of consumer demands eventually brings in profits for insurers.

Insurance products, being intangible ones, need to be marketed in a manner that efficiently meets the requirements of consumers. In the future, much more so than now, insurance products will tend to be purchased in answer to consumers' explicit needs, and the quality of insurance service will definitely affect consumer decisions on whether or not to purchase a certain product. It is hence no exaggeration to say that the survival of insurance companies will be wholly dependent on the quality of their services. 
For the betterment of customer satisfaction, thorough service should be provided from the time of policy issuance up to its expiry. Ancillary services should also be improved, in a way that ensures more facilitated services from the customers' viewpoints. In the near future, their overall financial consulting capability, combined with the level of their insurance services, will also be an important factor in customers' standards in regard to insurance companies. Diversified services ought therefore to be provided to clients, by expanding and developing the customer information system.

Meantime, as one example of substantial enhancement in the quality of services, it seems desirable to pursue the one-stop financial service strategy - which can aggressively respond to the changing financial environment and satisfy the ever-diversifying needs of consumers.

\section{Forecast for the Korean insurance industry}

The growth of the insurance industry is not easy to forecast, due to various unforeseeable factors. For example, particularly, in life insurance, savings-type insurance is closely related to the level of national income, demographic changes in national population, and the level of consumer prices; protection-type insurance, on the other hand, is related with the frequency of loss occurrence. As far as non-life insurance is concerned, it is directly affected by the number of manufacturing companies and registered automobiles, and by the growth of international trade volumes and residential construction, while being indirectly influenced by the level of national income. It should therefore be clarified in advance that the forecast made in this section has been based on past overall trends of the above-mentioned factors.

During the next few years, the Korean insurance industry is expected to continue the growth it began in the past. However, it has become difficult to attain the unprecedented rapid growth it enjoyed in the seventies and eighties; rather, it will enter a period of gradual growth in a stable development stage. This trend is expected to result in the Korean insurance industry deemphasizing its previous drive for sales growth, in favor of enhancing profitablity, thus making management efficiency much improved and pushing Korea into the ranks of the industry's advanced countries.

Taking a look at life insurance, it has attained a rapid growth rate, ranging around $50 \%$ on average in the seventies and at least up to the mid-eighties. However, since the latter part of the eighties, its growth velocity has been noticeably losing momentum. This trend will continue in the nineties, and the annual average growth rate during the period of 1994-2000 will be at a 7-8\% level.

Turning to non-life insurance, it is forecasted that the rapid growth of premium, which was commonly in the $40 \%$ range in the seventies and $25 \%$ in the eighties, will not continue. However, insurable interests in the automobile insurance line, which occupies the lion's share in the non-life section, will keep growing, due to the increasing number of registered automobiles, while international trade volumes will also persistently increase. What is more, new risks will appear and the people's way of thinking will be enhanced, accelerating the growth rate to an annual average of $17-18 \%$, higher than that of the life section. 
In life and non-life insurance as a whole, the growth rate will range around slightly more than $10 \%$ on an annual average basis through the year 2000 .

This anticipated growth pattern in the life and non-life insurance sectors will help improve the imbalance between them in terms of premium volume. By the year 2000 the proportional composition of life and non-life will have moved to $66: 34$, from the existing 78:22.

Turning to overseas reinsurance transactions, the inward reinsurance business will record immaterial growth due to conservative underwriting. The outward reinsurance business, however, will increase significantly, recording a $10 \%$ annual growth rate through the year 2000, accompanying the expansion of large industrial risks following economic development. 